Sains Malaysiana 47(11)(2018): 2831-2840

http://dx.doi.org/10.17576/jsm-2018-4711-26

\title{
Microcontroller-Based Moisture Meter for Ginger
}

(Meter Kelembapan Berasaskan Mikropengawal untuk Halia)

\author{
NUR BiHA MOHAMED NAFIS, ZULKIFLY ABBAS*, JUMIAH HASSAN, NORADIRA SUHAIME, \\ LEE KIM YeE, YOU KOK YEOW \& ZAULIA OTHMAN
}

\begin{abstract}
This paper describes the development of a simple method to determine the permittivity and moisture content (m.c.) of ginger. The measurement system consists of a microwave sensor, directional coupler and a PIC microcontroller. The microwave sensor is a square flanged open-ended coaxial (OEC) sensor made from SMA stub contact panel with outer diameter (O.D) $4.10 \mathrm{~mm}$. The microwave oven drying method was used to determine the actual m.c. of the ginger. All data acquisition, processing and display were accomplished using a PIC 16F690 microcontroller programmed using Flowcode software. The actual values of the permittivity of ginger were obtained by using the Agilent (now Keysight Technologies) 85070B dielectric probe along with a HP $8720 B$ Vector Network Analyzer (VNA). The results showed good relationships between m.c., permittivity (dielectric constant $\left(\varepsilon^{\prime}\right)$ and loss factor $\left(\varepsilon^{\prime \prime}\right)$ ) and reflected voltage. The calibration equations between reflected voltage and m.c. have been established for the sensor. The measurement system provides a simple,fast and accurate technique to predict m.c., $\varepsilon^{\prime}$ and $\varepsilon^{\prime \prime}$ of ginger from reflected voltage measurements alone. The accuracy in determination of m.c., $\varepsilon^{\prime}$ and $\varepsilon^{\prime \prime}$ in ginger was within $2.9 \%, 2.7 \%$, and $3.6 \%$, respectively.
\end{abstract}

Keywords: Microcontroller; moisture content; open-ended coaxial sensor; permittivity; reflected voltage

\section{ABSTRAK}

Kertas ini menghuraikan mengenai pembangunan satu kaedah yang mudah untuk menentukan kadar ketelusan dan kandungan lembapan (m.c.) halia. Sistem pengukuran ini terdiri daripada sensor gelombang mikro, pengandingan arah dan mikropengawal PIC. Sensor gelombang mikro adalah pengesan berpaksi terbuka bersegi empat (OEC) yang dibuat daripada panel sentuh stub SMA dengan diameter luar (O.D) $4.10 \mathrm{~mm}$. Kaedah pengeringan ketuhar gelombang mikro digunakan untuk menentukan m.c. halia yang sebenar. Semua pemerolehan, pemprosesan dan paparan data telah diperoleh dengan menggunakan mikropengawal PIC 16F690 yang diprogram menggunakan perisian Flowcode. Nilai sebenar kadar ketelusan untuk halia diperoleh dengan menggunakan Agilent (sekarang Keysight Technologies) $85070 B$ peranti deria sepaksi hujung terbuka sekali dengan penganalisis rangkaian vektor HP $8720 B$ (VNA). Keputusan menunjukkan hubungan yang baik antara m.c., kadar ketelusan (pemalar dielektrik $\left(\varepsilon^{\prime}\right)$ dan faktor kehilangan $\left.\left(\varepsilon^{\prime \prime}\right)\right)$ serta voltan yang dipantulkan. Persamaan penentukuran antara voltan yang dipantulkan dan m.c. telah dibangunkan untuk sensor tersebut. Sistem pengukuran ini menyediakan teknik yang mudah, cepat dan tepat untuk meramalkan m.c., $\varepsilon^{\prime}$ dan $\varepsilon^{\prime \prime}$ halia daripada pengukuran voltan yang dipantulkan sahaja. Ketepatan dalam menentukan m.c., $\varepsilon^{\prime}$ dan $\varepsilon^{\prime \prime}$ halia adalah dalam $2.9 \%, 2.7 \%$ dan $3.6 \%$.

Kata kunci: Kadar ketelusan; kandungan lembapan; mikropengawal; pengesan sepaksi terbuka; pantulan voltan

\section{INTRODUCTION}

Ginger (Zingiber officinale Rosc.) which belongs to the family of Zingiberaceae is a type of underground stem, in which its rhizome is commonly used as a spice and herbal medicine. The quality of ginger depends on moisture content (m.c.), density, fiber and gingerol content. Accurate measurement of ginger m.c. is critical in postharvest process such as marketing, processing and storing (Li et al. 2011). The fresh ginger, which is harvested 5-7 months after plantation has about $80-93 \%$ of m.c., hence is suitable to be used as preserving ginger. Meanwhile, the fully mature ginger, which is usually harvested 8-9 months after plantation, containes higher fiber but lower in m.c. than the fresh ginger, hence is suitable as dried ginger and oil (Dubey \& Tiwari 2008). The variation in m.c. can occur due to cultivar variation, area of cultivation and processing methods.

Many external factors such as temperature, relative humidity, fungi and bacteria soft rot that could lead to quality deterioration especially during post-harvest handling process. After the harvest, it is important to prevent the ginger rhizome from microbial contamination, mould growth and decay. Pressure washing (FAO 2002) and appropriate condition for ginger storage which is at a temperature of $22^{\circ} \mathrm{C}$ and $70 \%$ relative humidity (Usaid 2014), are steps that highly recommended to maintain the m.c. in the appropriate range, this will then help to preserve the quality and freshness of the harvested ginger. 
Several techniques have been proposed to determine m.c. in gingers. The oven drying technique is the standard method for m.c. measurement (ASAE 1995). However, it requires high temperature, long processing time and not suitable for in-situ. Measurement of Karl Fischer technique is relatively the most accurate technique for m.c. measurement (Ruan \& Chen 1998). The Karl Fischer technique utilized both extraction and chemical titration procedures (Sigma Aldrich 2003) for m.c. measurements. Meanwhile, in the Infrared technique, the radiated energy is transferred from the heating element to the product surface without heating the surrounding air. The infrared waves penetrate the ginger samples and is converted to heat energy to evaporate the water in the samples (Ginzburg 1969). However, both Karl Fischer and Infrared techniques are limited to small sample size such as powders (Nagarajan et al. 2006), laborious and time-consuming.

In recent years, microwave technique has been gaining interest for fast and accurate measurement of m.c. in agricultural products. The permittivity of agricultural products depends on m.c., density, composition and structure, water activity, temperature and frequency of the applied field (Ragni et al. 2006). Most microwave techniques for assessing crops quality are based on m.c. (Yeh et al. 1994). The measurement of m.c. in solid or liquid using microwave method is known to be accurate and rapid. This method takes advantage of the dielectric properties of water molecule which has high electric dipole moment due to the separation of charges. Water has significantly high dielectric constant $\left(\varepsilon^{\prime}\right)$ at radio and microwave frequency because of the high dipole moment of water molecule. Water molecules will partially align themselves under applied external electric field. However, water molecules cannot instantaneously orient themselves to electric field because of molecular interaction between water molecules, resulting in dispersion in polarization. The orientation of water molecule to changing electric field also causes some energy of the electromagnetic field to be dissipated as heat (Kupfer 2005). Because of these effects, microwave sensors are the best tools to indirectly measure m.c. in solid agricultural products. Measurement of m.c. remains the prime interest in the application of microwave method for agriculture products and eventually helps in the evaluating the quality of agriculture products (Ragni et al. 2006).

One of the most popular microwave techniques for assessing the quality of samples is based on the openended coaxial (OEC) line. OEC was originally designed to measure permittivity of samples. OEC techniques have been used to determine m.c. in latex (Yahaya et al. 2014) and maize (Jusoh et al. 2011) with high accuracy. OEC sensor provides a fast and accurate method for m.c. measurement. The low-cost OEC sensor requires only one-port calibration procedure and minimal preparation (Isengard 1995). Unfortunately, the previous OEC techniques to measure permittivity require a network analyzer to measure the reflection coefficient $(\Gamma)$ which is too expensive and bulky to be used for in-situ measurements.
In this work, the used of small and cheap microcontroller is important for data acquisition and can instantly displays the data acquired. The developed cost-effective microcontroller-based moisture meter operating at $2 \mathrm{GHz}$ frequency offers a direct in-situ measurement especially for ginger quality checking process in the market, by replacing the bulky signal generator with a miniaturized signal source such as the voltage controlled oscillator. This paper presents a simpler, lower cost, faster and more accurate technique for determination of both permittivity and m.c. in ginger using an OEC sensor.

\section{MATERIALS AND METHODS}

\section{SAMPLE PREPARATION AND MOISTURE CONTENT MEASUREMENT}

Fresh gingers were bought from the wet market. After removing its skin, the samples were then cut into square shaped slices of $3 \mathrm{~cm}$ length and $1.5 \mathrm{~cm}$ thickness.

The actual m.c. of ginger was determined by using microwave oven-drying method. This drying method utilized the official AOAC method (AOAC 2000; Nielsen 2010) but modifications had been made on its time and power setting. According to Michael et al. (1991), all samples were dried at $550 \mathrm{~W}$ microwave power for $20 \mathrm{~min}$ to ensure minimum water requirement. All the samples were firstly weighed before the drying process by using the Shimadzu Y220 electronic weight balance (Shimadzu Corporation, Japan) with $0.1 \mathrm{mg}$ precision. After the drying process, the samples were allowed to cool at room temperature of $25^{\circ} \mathrm{C}$ before being weighed again. The cycle of this procedure was repeated for every sample until a constant mass of $\pm 0.5 \mathrm{mg}$ was achieved (Yahaya et al. 2014). The wet basis m.c. of a material is defined as Bouraoui et al. (1993):

$$
\text { m.c. }(\%)=\frac{m_{\text {wet }}-m_{d r y}}{m_{\text {wet }}} \times 100 \%
$$

where $m_{w e t}$ and $m_{d r y}$ are the initial mass before drying and the final mass after drying, respectively.

\section{MEASUREMENT OF THE PERMITTIVITY}

The permittivity measurement setup which includes the Agilent (now Keysight Technologies) 85070B dielectric probe (Keysight Technologies, Inc., California), a coaxial cable, a high density shorting block for the calibration, adapters and a HP 8720B Vector Network Analyzer (VNA) (Keysight Technologies, Inc., California), is used for data collection of the permittivity results ranging from 1.0 to 4.0 GHz. The $\varepsilon^{\prime}$ and $\varepsilon^{\prime \prime}$ of each sample were acquired based on the $\Gamma$ values of the samples that is obtained when the material is in contact with the active tip of the probe (Blackham \& Pollard 1997). Air, deionized water and shorting block had been used as the calibration standards for the permittivity measurement. The measurement 
error for the dielectric constant $\left(\varepsilon^{\prime}\right)$ was \pm 0.05 (Agilent Technologies 2013). The information of permittivity at range between 1 and $4 \mathrm{GHz}$ will be beneficial for the development of the low cost portable instruments utilizing the existing telecommunication devices.

The samples were placed on an aluminium jack that can be raised up to give good support and maintained firm contact between the samples and also the Keysight dielectric probe (Nelson 2003). The samples were measured again on the opposite side of the samples to obtain the average permittivity values. For ginger, the uneven surface of each sample was cut flat to create a $1.5 \mathrm{~cm}$ thick slice to abide the minimum thickness requirement when using the Keysight dielectric probe as to avoid the microwave signal reaching the end face of the sample when using Keysight dielectric probe which based on the relationship between permittivity and the minimum thickness, $d$ specified by the manufacturer (Agilent Technologies 2013) as,

$$
d=\frac{20}{\sqrt{\varepsilon^{*}}}
$$

where $\varepsilon^{*}$ represents permittivity.

According to (2), higher $\varepsilon^{\prime}$ required smaller sample thickness. The Keysight dielectric probe can measure the value of $\varepsilon$ as lowest as 2.0 which equivalent to the value of $1.4 \mathrm{~cm}$ sample thickness.

The permittivity of the samples was first taken before placing in the microwave oven to undergo drying at $550 \mathrm{~W}$ microwave power level for $10 \mathrm{~min}$. The dried samples were cooled at room temperature $\left(25^{\circ} \mathrm{C}\right)$ before weighing. The permittivity of the samples was measured again and the drying continued for $2 \mathrm{~min}$ and the mass measurement process was repeated. The process was then continued until a constant mass was achieved which occupied a total of 20 min of drying process. Two sets of measurement were made; one for developing prediction models and another for validating the models.

\section{MEASUREMENT OF $\mathrm{pH}$}

The $\mathrm{pH}$ of the ginger samples with different m.c. percentage was measured based on the AOAC (1990) procedure by using $\mathrm{pH} 211$ Microprocessor $\mathrm{pH}$ meter (Hanna Instruments, Woonsocket, United States of America). The ginger samples were blended by using a kitchen blender. The $5 \mathrm{~g}$ of blended ginger was diluted with $20 \mathrm{~mL}$ of distilled water and stirred by using a stirrer. Then, a clean, standardized electrode was dipped into the diluted ginger solution and the $\mathrm{pH}$ measurement was taken (Hanna Instruments 2016). The value of $\mathrm{pH}$ taken for each sample was the averaged of five replications. The statistical analysis of the data was conducted by using Analysis of Variance (ANOVA) (SAS Institute 1989).

\section{MICROCONTROLLER: MEASUREMENT OF REFLECTED VOLTAGE}

The measurement system as shown in Figure 1 consists of a signal generator (SG), a directional coupler, OEC sensor, a diode detector, a PIC16F690 microcontroller and liquid crystal display panel (LCD) with Hitachi 44780 controller. The signal generator used in this work was a Mini-Circuits USB Synthesized SSG-4000HP signal generator with a

(a)

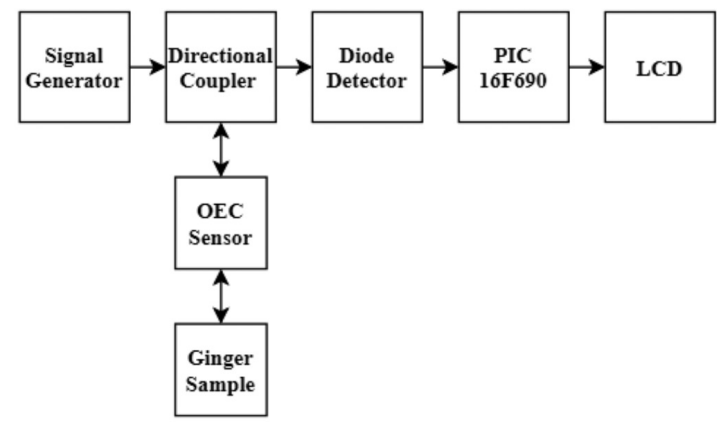

(b)

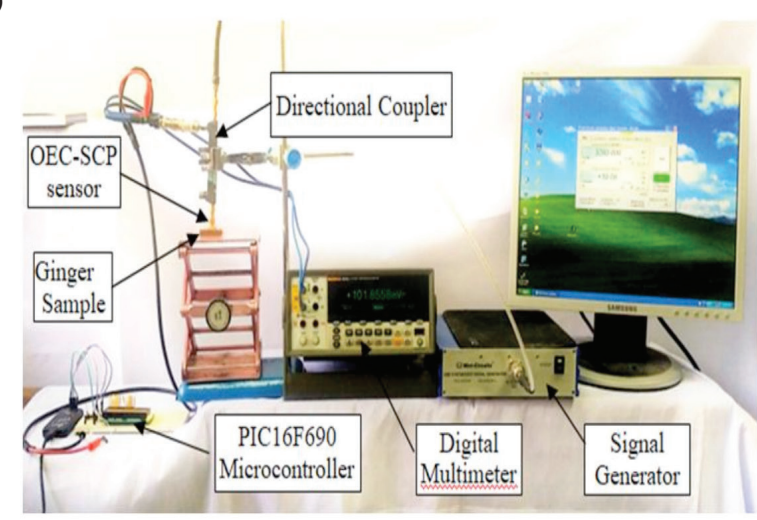

(c)

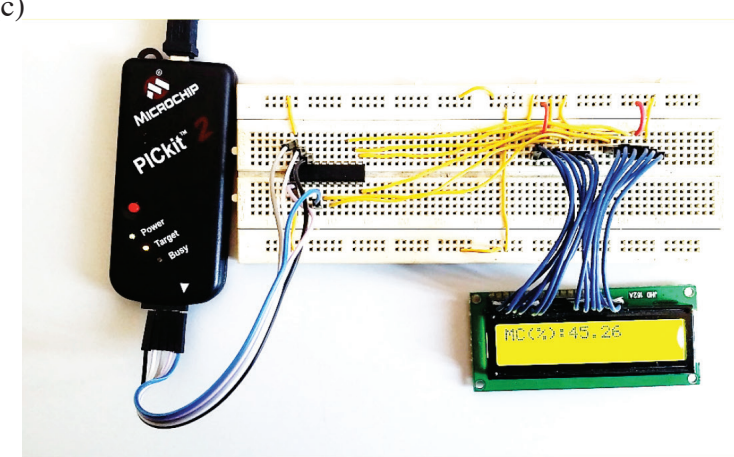

(d)

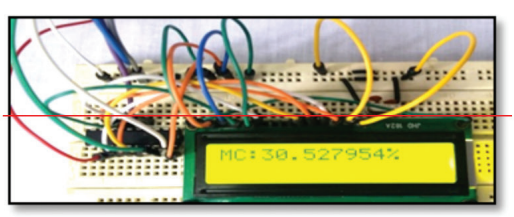

FIGURE 1. The setup of reflectometer; (a) block diagram, (b) overview measurement setup, (c) LCD display and (d) OEC sensor 
constant $20 \mathrm{dBm}$ output power at $2 \mathrm{GHz}$. The power and frequency setup of the signal generator was accomplished using a PC. The measurement system can be made portable by replacing the bulky signal generator with a miniaturized signal source such as the voltage controlled oscillator.

The OEC sensor was a SMA stub contact panel where the protruding inner and outer parts were cut to form an open-ended coaxial with outer and inner diameters 1.3 and $4.1 \mathrm{~mm}$, respectively. The inner and outer conductors of the sensor were separated by PTFE. The flange dimension was $12.7 \times 12.7 \mathrm{~mm}$

The ATMC123E-20 directional coupler was used to separate incident signal from SG and the OEC's reflected signal due to ginger. The ATMC123E-20 directional coupler was specified for frequency range from $1-4 \mathrm{GHz}$, with 20 $\mathrm{dB}$ coupling, $0.45 \mathrm{~dB}$ insertion loss and max VSWR 1.2:1.2. Furnishing the termination of incident port internally ensured high performance of the 3 ports ATMC123E-20 directional coupler (Mini Circuits 1999). The incident voltage is always constant, while the only changes in voltage is the reflected voltage, which eventually does not make any changes to the values of $\Gamma$. The reflected microwave signals were converted to direct current (DC) voltage using the MIDISCO MDC1087-S Zero Bias Schottky diode detector with $\pm 0.5 \mathrm{~dB}$ flatness, max VSWR 1.2:1.

The cheap and small in size of PIC16F 690 microcontroller which is manufactured by Microchip company was used to convert the analog output from the diode detector to digital. The PIC16F690 microcontroller is a 20-pin 8-bit CMOS flash using the Nano-watt technology, in which offers energy saving features of the total instrumentation system, with added values such as extensive operating voltage range $(2.0 \mathrm{~V}-5.5 \mathrm{~V})$ and power manage technology from direct current to $40 \mathrm{MHz}$ alternative current (Microchip 2015). The voltage readings at room temperature $25^{\circ} \mathrm{C}$ were verified with a FLUKE 8846A 6-1/2 Digital Precision Multimeter. All the data acquisition, processing and LCD display were programmed using FlowCode version 5.5.

\section{SOFTWARE DEVELOPMENT: FLOWCODE}

A PIC16F690 program was developed using Flowcode software for data acquisition and computation of m.c. of the samples from the measured reflected voltage. The program also includes the calibration equation to calculate m.c. from the measured reflected voltage. The accuracy calibration equation was tested and analyzed by comparing the predicted m.c. with actual m.c. obtained from the standard oven drying method. The program flowchart is shown in Figure 2.

The program was used to calculate m.c. from the output voltage of the microwave diode detector. The m.c. values were displayed on the LCD panel. The Flowcode program was uploaded into the PIC16F690 microcontroller using the PICkit ${ }^{\mathrm{TM}} 2$ Programmer.

The LCD component was selected from the Flowcode Components Toolbar. The 16-pin LCD module has an 8-bit data bus labeled D0 to D7. However only data pins D4 to (a)

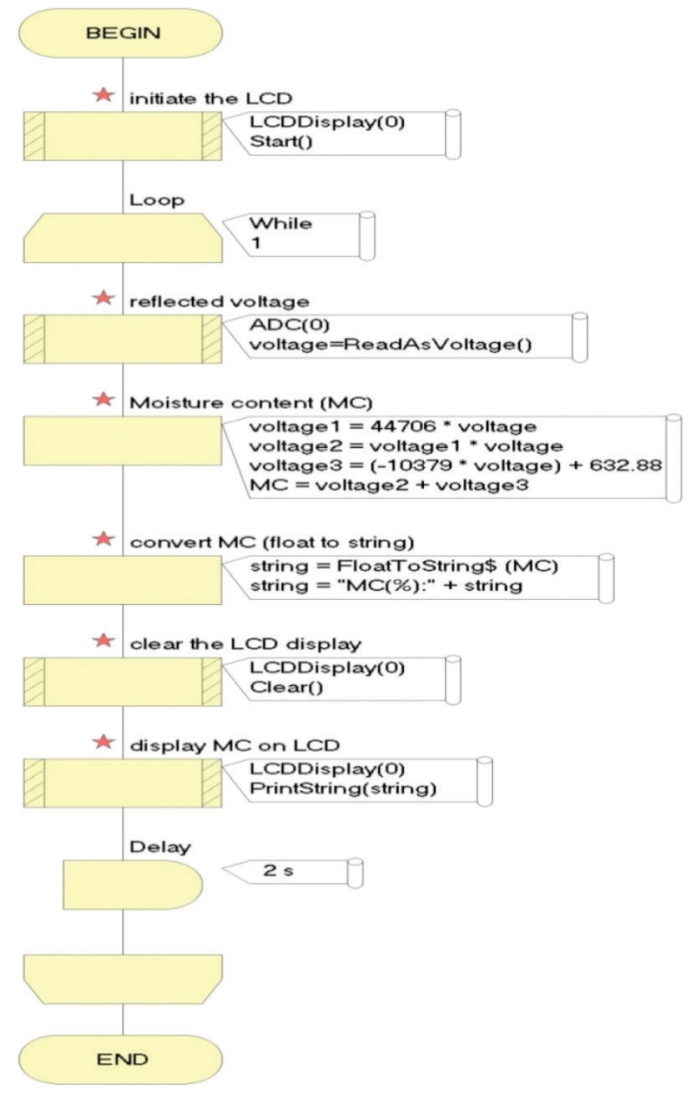

(b)

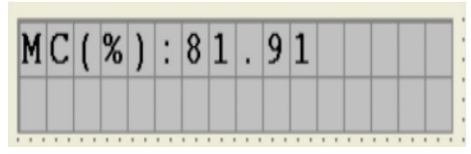

FIGURE 2. The Flowcode software that include:

(a) Graphical programming; (b) Panel view

D7 were interfaced to PIC16F690 microcontroller via port C. Pin number 13 of the PIC16F690 microcontroller was assigned to the LCD. Simulation results were realized by using Component Macro icon to initiate the LCD display. Continuous display was achieved by applying Loop icon. The $A D C$ icon was used to acquire the voltage data and perform analog to digital conversion. The calculation of the m.c. from the measured voltage using the calibration (4) implemented using the Calculation icon. Due to Flowcode limitation, the calibration equation was split into 3 short equations. The floating variable m.c. was converted into string variable for the LCD to display the m.c. in digital format.

The PIC16F690 executes 1 million instructions per second. For the LCD display to be visible to the eyes, the software loop execution needs to be slowed down. This is accomplished by including the Delay icon. In this work the delay was set to $2 \mathrm{sec}$ interval. The Flowcode program was uploaded into the PIC16F690 microcontroller using the PICkit ${ }^{\mathrm{TM}} 2$ Programmer. 


\section{RESULTS AND DISCUSSION}

\section{PERMITTIVITY OF GINGER: DIELECTRIC CONSTANT, $\varepsilon^{\prime}$} AND LOSS FACTOR, $\varepsilon^{\prime \prime}$

Figure 3 shows the variation of the $\varepsilon^{\prime}$ and $\varepsilon^{\prime \prime}$ of water and ginger with frequency of various percentage of m.c. It can be clearly seen that the linear decrease in the dielectric constant of water, $\varepsilon^{\text {'water }}$ with frequency was complemented with a linear increase in $\varepsilon^{\prime \text { water }}$ with frequency. The $\varepsilon^{\prime}$ for all ginger samples closely followed the profile of water. In contrast, two different sets of relationships between $\varepsilon^{\prime \prime}$ and frequency can be observed at the vicinity of the critical frequency $2.5 \mathrm{GHz}$. Initially, $\varepsilon^{\prime \prime}$ for all ginger samples decreased with frequency due to effects of ionic conductivity and bound water relaxation which greatly influence the values of $\varepsilon^{\prime \prime}$ but have less of an effect on the $\varepsilon^{\prime}$ (Rao et al. 2005). Above $2.5 \mathrm{GHz}, \varepsilon^{\prime \prime}$ values increased slowly as the frequency approaches free water relaxation frequency due to the dipole orientation of the water (Venkatesh \& Raghavan 2004).

The potential of hydrogen $(\mathrm{pH})$ can have significant effects on dielectric properties (Shukla \& Anantheswaran 2001). Based on (3), the theoretical relationship between the ionic contribution to the $\varepsilon^{\prime \prime}$ and the conductivity $(\sigma)$ showed that the $\varepsilon$ "increased with conductivity of material.

$$
\varepsilon^{\prime \prime}=\frac{\sigma}{2 \pi f \varepsilon_{o}}
$$

where $\sigma$ is the conductivity; $f$ is the frequency; and $\varepsilon_{0}$ is the permittivity of free space.

In this work, the effect of m.c. on $\mathrm{pH}$ and $\sigma$ is shown in Table 1. The $\mathrm{pH}$ increased from 6.14 to 6.27 for corresponding increased in m.c. from $40.2 \%$ and $80.9 \%$. The change of $\mathrm{pH}$ had a significant effect on

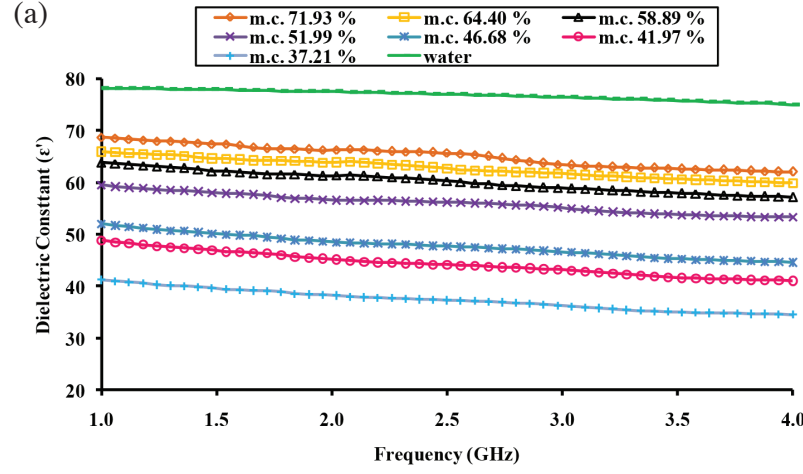

(b)

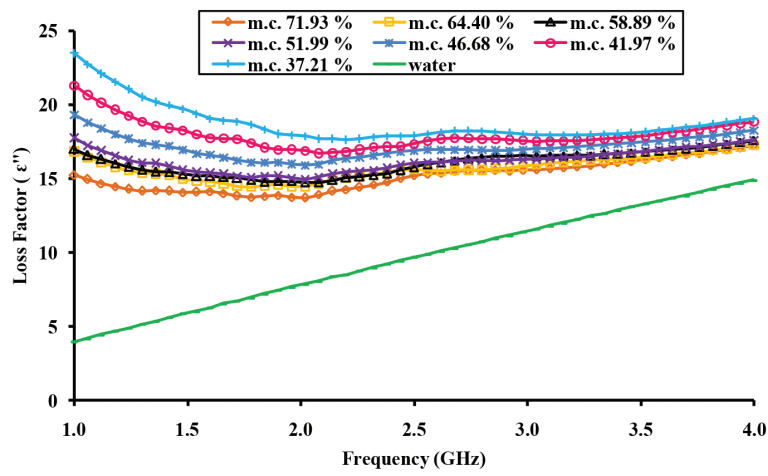

FIGURE 3. Permittivity of ginger; (a) $\varepsilon^{\prime}$ and (b) $\varepsilon^{\prime \prime}$ of ginger with frequency at various percentages of m.c.

the electrostatic charge of the molecule and affected the dielectric properties of ginger. In the presence of low $\mathrm{pH}$, the $\varepsilon^{\prime \prime}$ increased significantly. For ginger sample, the lower the m.c., on the other hand, have higher the $\varepsilon^{\prime \prime}$. The measured $\mathrm{pH}$ value shows that lower m.c. of ginger would have lower $\mathrm{pH}$ value which causes higher value of $\sigma$, and

TABLE 1. (a) The $\mathrm{pH}$ and $\sigma$ values of ginger based on different percentage of m.c. and (b) statistical analysis using ANOVA for relationship between m.c. with $\mathrm{pH}$ and $\sigma$

(a)

\begin{tabular}{ccc}
\hline m.c. $(\%)$ & $\mathrm{pH}$ & $\sigma$ \\
\hline 40.2 & 6.14 & 2.20 \\
50.5 & 6.16 & 1.86 \\
60.4 & 6.19 & 1.58 \\
70.3 & 6.22 & 1.36 \\
80.2 & 6.27 & 1.20 \\
\hline
\end{tabular}

(b)

\begin{tabular}{cccccccc}
\hline Parameter & Source of Variation & $S S$ & $d f$ & $M S$ & $F$ & P-value & $F$ crit \\
\hline \multirow{3}{*}{$\mathrm{pH}$} & Between Groups & 7323.518 & 1 & 7323.518 & 58.8188 & $5.91 \mathrm{E}-05$ & 5.317655 \\
& Within Groups & 996.0785 & 8 & 124.5098 & & & \\
& Total & 8319.597 & 9 & & & & 5.317655 \\
$\sigma$ & Between Groups & 8607.986 & 1 & 8607.986 & 69.09158 & $3.31 \mathrm{E}-05$ & \\
& Within Groups & 996.7046 & 8 & 124.5881 & & & \\
& Total & 9604.691 & 9 & & & & \\
\hline
\end{tabular}


thus would increase the $\varepsilon^{\prime \prime}$ values based on (3) (Thumm et al. 2012). The decrease of $\mathrm{pH}$ of ginger as m.c. decreased can minimize intermolecular electrostatic repulsion which results in increase in $\varepsilon^{\prime \prime}$ (Rao et al. 2005). Table 1(b) shows that the analysis of variance (ANOVA) suggests the small value of $p$-value indicates a good correlation between different m.c. percentage of ginger that has significant differences $(p<0.05)$ with $\mathrm{pH}$ and $\sigma$.

\section{CORRELATION BETWEEN PERMITTIVITY AND M.C.}

The effect of m.c. on $\varepsilon^{\prime}$ and $\varepsilon^{\prime \prime}$ of ginger at $1 \mathrm{GHz}, 2 \mathrm{GHz}$, $3 \mathrm{GHz}$ and $4 \mathrm{GHz}$ can be observed clearly from Figure 4. Figure 4(a) shows $\varepsilon^{\prime}$ increased exponentially positive with m.c. whilst for $\varepsilon^{\prime \prime}$ decreased exponentially negative with m.c. as expected from Figure 4(b). The regression equations listed in Table 2 can be used to predict both $\varepsilon^{\prime}$ and $\varepsilon^{\prime \prime}$ from the values of m.c. Figure 4 shows that all $\varepsilon^{\prime}$ profiles are almost similar but not the $\varepsilon^{\prime \prime}$. Based on Figure 4(a), the higher percentage of m.c. would have higher $\varepsilon^{\prime}$ values because water is a strong polar solvent (Ryynanen 1995) that has high dipole moment of water molecules. Thus, it is expected that water has significantly high $\varepsilon^{\prime \prime}$ at microwave frequencies. The operating frequency can highly affect the electric polarization of water. At low frequency, the water molecules were able to follow the vibration of the microwave which decreased the value of $\varepsilon^{\prime}$. In contrast, the ability of $\varepsilon^{\prime}$ to store energy is lower at high frequency and the molecules were no longer able to follow the vibration of microwave at higher frequency and the energy is dissipated as heat which resulted of lower values of $\varepsilon^{\prime}$ and higher values of $\varepsilon^{\prime \prime}$ (Kupfer 2005).

Further analysis of $\varepsilon^{\prime \prime}$ profiles shown in Figure 4(b), suggests existence of a critical m.c. where the transition from rapid to slow change in $\varepsilon^{\prime \prime}$ occurred. The critical m.c. was found to increase with higher operating frequencies. The critical m.c. at $1 \mathrm{GHz}, 2 \mathrm{GHz}, 3 \mathrm{GHz}$ and $4 \mathrm{GHz}$ were $52 \%, 53 \%, 54 \%, 55 \%$, respectively.

The $\Gamma$ of the OEC sensor can be expressed in terms of impedance mismatch at the interface between the sensor and sample

$$
\Gamma=(1-\tilde{Y}) /(1+\tilde{Y})
$$

The normalized admittance $\tilde{Y}$ is the ratio of the admittance due to the sample with respect to the characteristic admittance of the sensor (Abbas et al.2005), i.e.,

$$
\tilde{Y}=Y\left(\omega, \varepsilon^{*}\right) / Y_{o}
$$
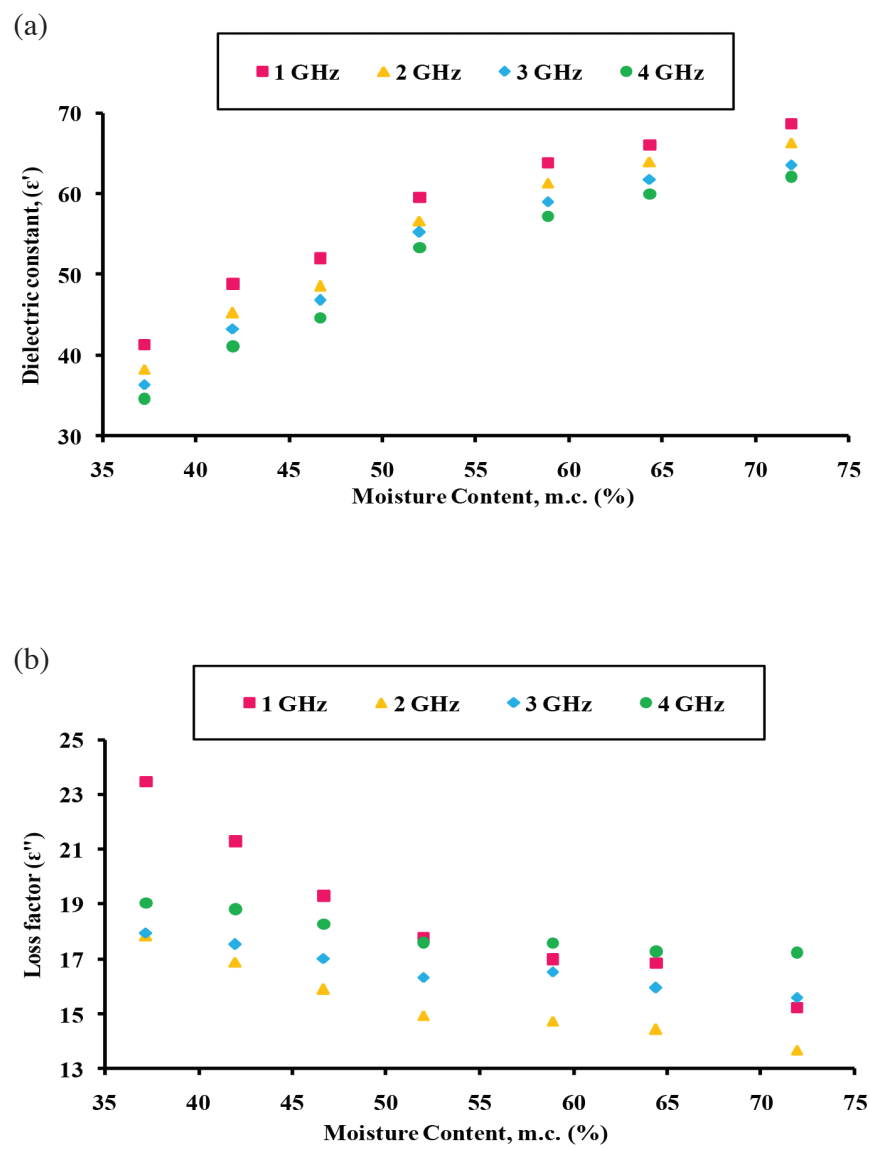

FIGURE 4. The relationship between m.c. and (a) $\varepsilon^{\prime}$ and (b) $\varepsilon^{\prime \prime}$ of ginger various at $1 \mathrm{GHz}, 2 \mathrm{GHz}, 3 \mathrm{GHz}$ and $4 \mathrm{GHz}$ 
TABLE 2. The relationship between $\varepsilon^{\prime}$ and $\varepsilon^{\prime \prime}$ of ginger with m.c. at various selected frequency

\begin{tabular}{ccccc}
\hline $\begin{array}{c}\text { Frequency } \\
(\mathrm{GHz})\end{array}$ & Dielectric constant $\left(\varepsilon^{\prime}\right)$ & Regression, $\mathrm{R}^{2}$ & Loss factor $\left(\varepsilon^{\prime \prime}\right)$ & ${\text { Regression, } \mathrm{R}^{2}}$ \\
\hline 1 & $\varepsilon^{\prime}=-0.018$ (m.c. $)^{2}+2.844$ m.c. -38.11 & 0.993 & $\varepsilon^{\prime \prime}=0.006$ (m.c. $)^{2}-0.882$ m.c. +47.58 & 0.974 \\
2 & $\varepsilon^{\prime}=-0.018$ (m.c. $)^{2}+2.866$ m.c. -42.54 & 0.993 & $\varepsilon^{\prime \prime}=0.002$ (m.c. $)^{2}-0.421$ m.c. +29.52 & 0.976 \\
3 & $\varepsilon^{\prime}=-0.020$ (m.c. $)^{2}+3.032$ m.c. -48.25 & 0.991 & $\varepsilon^{\prime \prime}=0.001$ (m.c. $)^{2}-0.183$ m.c. +23.25 & 0.950 \\
4 & $\varepsilon^{\prime}=-0.019$ (m.c. $)^{2}+2.927$ m.c. -47.71 & 0.991 & $\varepsilon^{\prime \prime}=0.001$ (m.c. $)^{2}-0.243$ m.c. +25.82 & 0.967 \\
\hline
\end{tabular}

where $\omega$ is the angular frequency. The complex permittivity, $\varepsilon^{*}=\varepsilon^{\prime}-j \varepsilon^{\prime \prime}$ where the real and imaginary parts are termed as the $\varepsilon^{\prime}$ and $\varepsilon^{\prime \prime}$, respectively.

The permittivity $\varepsilon^{*}$ of moist materials is a function of m.c., density $(\rho)$, temperature (T) and frequency (Kraszewski 1980), i.e.,

$$
\varepsilon^{*}=f(m . c, \rho, T, \text { frequency })
$$

Based on previous study (Onu \& Okafor 2003), it was reported that almost constant bulk density of ginger between 1.50 and $1.51 \mathrm{kgm}^{-3}$ for ginger with $\mathrm{m}$.c. between $45.6 \%$ and $81.0 \%$. Assuming constant density for all samples, then at any given frequency, all the parameters are remained constant except for m.c. The $\Gamma$ can also be expressed in terms of the reflected voltage $\left(V_{R}\right)$ and incident voltage $\left(V_{I}\right)$

$\Gamma=\frac{V_{R}}{V_{I}}$
From (6) and (7), it can be clearly seen that the $V_{R}$ depends only on m.c. if the values of $\rho, \mathrm{T}$ and frequency are kept constant.

\section{RELATIONSHIP BETWEEN $\mathrm{V}_{\mathrm{R}}, \tilde{Y}$ AND M.C.}

The relationship between the $V_{R}$ of the OEC sensor and m.c. for ginger at $2 \mathrm{GHz}$ are shown in Figure 5(a). The sensor can be used to identify ginger maturity level based on m.c. classification. Voltage readings for all fresh gingers were equal or more than $0.15 \mathrm{~V}$, whilst fully matured ginger recorded voltage readings between $0.13 \mathrm{~V}$ and $0.15 \mathrm{~V}$. The dried samples typically less than $40 \%$ m.c. (Sreekumar et al. 2002) are those with voltage readings less than $0.13 \mathrm{~V}$. Figure 5(b) shows that $\tilde{Y}$ decreased with increasing m.c. of the ginger. Based on (4) and (7), the higher the m.c. of ginger samples would increase the value of $V_{R}$, which also increased the value of $\Gamma$ but decreased the value of $\tilde{Y}$. Table 3 suggests a good correlation between $V_{R}$ and $\tilde{Y}$ with different m.c. percentage of ginger that have significant

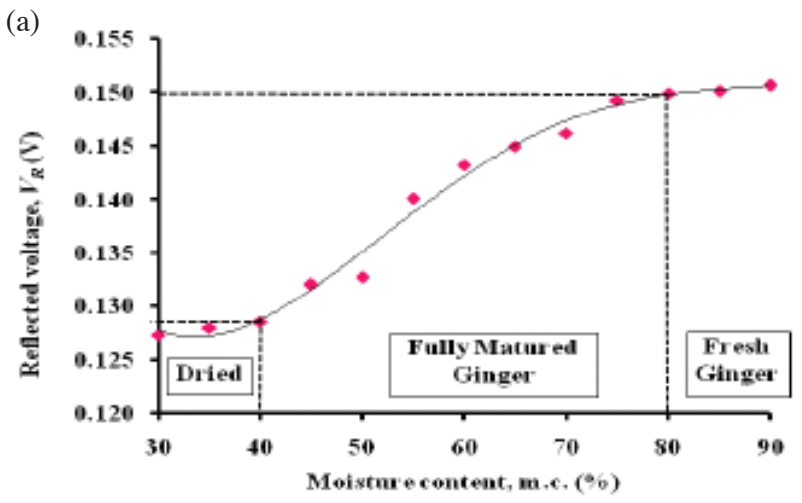

(b)

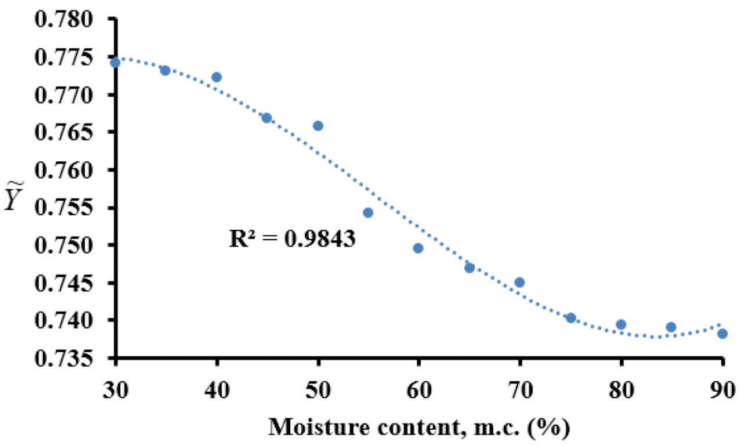

FIGURE 5. Variation in (a) $V_{R}$ and (b) $\tilde{Y}$ with m.c. from $30 \%$ to $90 \%$ of ginger 
TABLE 3 . The statistical analysis using ANOVA for relationship between $V_{R}$ and $\tilde{Y}$ with m.c.

\begin{tabular}{cccccccc}
\hline Parameter & Source of Variation & SS & $d f$ & $M S$ & $F$ & P-value & F crit \\
\hline \multirow{2}{*}{$V_{R}$} & Between Groups & 23290.77 & 1 & 23290.77 & 122.8524 & $6.35 \mathrm{E}-11$ & 4.259677 \\
& Within Groups & 4550.001 & 24 & 189.5834 & & & \\
& Total & 27840.77 & 25 & & & & \\
$\tilde{Y}$ & Between Groups & 22815.43 & 1 & 22815.43 & 120.3451 & $7.82 \mathrm{E}-11$ & 4.259677 \\
& Within Groups & 4550.002 & 24 & 189.5834 & & & \\
\hline
\end{tabular}

TABLE 4 Comparison between actual and predicted values of ; (a) m.c., (b) $\varepsilon^{\prime}$ and (c) $\varepsilon^{\prime \prime}$

(a)

\begin{tabular}{ccc}
\hline Actual m.c. $(\%)$ & Predicted m.c. $(\%)$ & Relative error $(\%)$ \\
\hline 36.5 & 34.1 & 6.5 \\
40.5 & 39.6 & 2.3 \\
45.3 & 46.0 & 1.5 \\
51.2 & 51.7 & 1.0 \\
54.8 & 55.0 & 0.4 \\
61.1 & 58.4 & 4.5 \\
66.4 & 63.2 & 4.8 \\
70.5 & 69.0 & 2.1 \\
75.5 & 74.1 & 1.8 \\
81.5 & 77.2 & 5.2 \\
85.3 & 83.3 & 2.3 \\
\hline \multicolumn{2}{c}{ Mean relative error $(\%)$} & 2.9 \\
\hline
\end{tabular}

(b)

\begin{tabular}{ccc}
\hline Actual $\varepsilon^{\prime}$ (Keysight dielectric probe) & Predicted $\varepsilon^{\prime}$ (OEC sensor) & Relative error (\%) \\
\hline 34.6 & 32.9 & 4.9 \\
38.2 & 37.5 & 1.8 \\
41.1 & 41.7 & 1.3 \\
44.7 & 46.5 & 4.2 \\
48.3 & 48.9 & 1.2 \\
50.5 & 51.4 & 1.7 \\
54.4 & 55.1 & 1.4 \\
57.2 & 59.0 & 3.1 \\
60.0 & 62.0 & 3.3 \\
62.1 & 64.5 & 3.9 \\
66.5 & 68.6 & 3.1 \\
\hline
\end{tabular}

(c)

\begin{tabular}{ccc}
\hline Actual $\varepsilon^{\prime \prime}$ (Keysight dielectric probe) & Predicted $\varepsilon^{\prime \prime}$ (OEC sensor) & Relative error (\%) \\
\hline 13.5 & 12.7 & 5.9 \\
14.0 & 13.3 & 4.7 \\
14.5 & 13.9 & 3.8 \\
14.9 & 14.6 & 2.1 \\
15.1 & 15.5 & 3.2 \\
15.7 & 16.3 & 3.9 \\
16.1 & 16.6 & 3.3 \\
16.6 & 17.1 & 3.3 \\
17.2 & 17.7 & 3.1 \\
17.5 & 18.1 & 3.3 \\
18.0 & 18.5 & 3.0 \\
\hline
\end{tabular}


differences $(p<0.05)$ based on the analysis of variance (ANOVA).

\section{MICROCONTROLLER: PERFORMANCE ANALYSIS OF M.C., $\varepsilon^{\prime}$ AND $\varepsilon^{\prime \prime}$}

The calibration equation was established to predict the amount of m.c., $\varepsilon^{\prime}$ and $\varepsilon^{\prime \prime}$ in the samples from the measured voltage of OEC sensor. The amount of m.c. in ginger can be predicted from the calibration equation by exchanging the $y$ and $x$ axes,

$$
\text { m.c. }=44706\left(V_{R}\right)^{2}-10379\left(V_{R}\right)+632.8
$$

In turn, (8) can be used to calculate the $\varepsilon^{\prime}$ and $\varepsilon^{\prime \prime}$ from (9) and (10) based on $V_{R}$.

$$
\begin{aligned}
& \varepsilon^{\prime}=-0.018(\text { m.c. })^{2}+2.866(\text { m.c. })-42.54 \\
& \varepsilon^{\prime \prime}=0.002(\text { m.c. })^{2}-0.421(\text { m.c. })+29.52
\end{aligned}
$$

The results are shown as follows where the relationship between $\varepsilon^{\prime \prime}$, and $V_{R}$ are

$$
\begin{aligned}
& \varepsilon^{\prime}=-61987\left(V_{R}\right)^{2}+18474\left(V_{R}\right)-1310.5 \\
& \varepsilon^{\prime \prime}=-1 \times 10^{6}\left(V_{R}\right)^{3}+530775\left(V_{R}\right)^{2}-74769\left(V_{R}\right)+3528.2
\end{aligned}
$$

The polynomial order of the (12) depends on the accuracy measurement when the actual and predicted values of the $\varepsilon^{\prime \prime}$ measurement are compared. The third polynomial order equation has higher accuracy than second order polynomial equation.

The accuracy of the OEC sensor for determination of permittivity and $\mathrm{m}$.c. of ginger were established by comparing the results of a new different batch of measurement data with the commercial Keysight $85070 \mathrm{~B}$ probe and the microwave oven drying method. The accuracies for m.c., $\varepsilon^{\prime}$ and $\varepsilon^{\prime \prime}$ were within $2.9 \%, 2.7 \%$ and $3.6 \%$, respectively. The comparison results are shown in Table 4 . For this work, the total cost of the microcontroller-based reflectometer is $90 \%$ cheaper than the price of a low end VNA.

\section{CONCLUSION}

A microcontroller-based instrumentation system has been developed successfully to determine both m.c. and permittivity of ginger. Calibration equations between $V_{R}$, permittivity and m.c. have been established for the sensor. The measurement technique provides a simple low cost approach for fast and accurate technique for determination of m.c., $\varepsilon^{\prime}$ and $\varepsilon^{\prime \prime}$ of ginger from the $V_{R}$ of the sensor. The accuracy in determination of m.c., $\varepsilon^{\prime}$ and $\varepsilon^{\prime \prime}$ in ginger were within $2.9 \%, 2.7 \%$ and $3.6 \%$, respectively.

\section{ACKNOWLEDGEMENTS}

The authors would like express utmost gratitude to Universiti Putra Malaysia (UPM) for the use of facilities for the research.

\section{REFERENCES}

Abbas, Z., Yeow, Y.K., Shaari, A.H., Khalid, K., Hassan, J. \& Saion, E. 2005. Complex permittivity and moisture measurements of oil palm fruits using an open-ended coaxial sensor. IEEE Sensors Journal 5: 1281-1287.

Agilent Technologies. 2013. Agilent 85070E Dielectric Probe Kit. California: Agilent Technologies Inc.

AOAC. 2000. Official Methods of Analysis of the Association of Official Analytical Chemists. 17th edition. Arlington VA: AOAC International.

ASAE. 1995. Moisture Measurement - Underground seeds S352.2. 2950 Niles Road, St. Joseph, Michigan, USA. American Society of Agricultural Engineers. MI 49085-9659.

Blackham, D.V. \& Pollard, R.D. 1997. An improved technique for permittivity measurements using a coaxial probe. IEEE Trans. on Instrumentation and Measurement 46: 1093-1099.

Bouraoui, M., Richard, P. \& Fichtali, J. 1993. A review of M.C. determination in foods using microwave oven drying. Food Research International 26: 49-57.

Dubey, K.R. \& Tiwari, S. 2008. Ginger, Production and PostHarvest Management. http://www.indg.in/agriculture/crop production techniques/technologies-for north-east-india/ ginger-production post-harvest. pdf.

FAO. 2002. Ginger: Post-harvest Compendium. Accessed from http//www.fao.org/fileadmin/userupload/inpho/docs/post harvest compendium-Ginger. pdf.

Ginzburg, A.S. 1969. Infrared radiation in food industry (in Polish). Warsaw: WydawnictwoNaukowo-Techniczne.

Hanna Instruments. 2016. pH Measurement SOP, 877. Accessed from https://hannainst.com/resources/ph/guides/ ph-measurement-sop--hanna-instruments.pdf

Isengard. H. 1995. Rapid water determination in foodstuffs. Trends in Food Science and Technology 6: 155-162.

Jusoh, M.A., Abbas, Z., Hassan, J., Azmi, B.Z. \& Ahmad, A.F. 2011. A simple procedure to determine complex permittivity of moist materials using standard commercial coaxial sensor. Measurement Science Review 11: 19-22.

Kraszewski,A. 1980. Microwave aquametry - A review. Journal of Microwave Power 15: 209-220.

Kupfer, K. 2005. Electromagnetic Aquametry. Germany: Springer.

Li, J., Xue, L., Liu, M.H., Lv, P. \& Yan, L.Y. 2011. Determination of moisture content in ginger using PSO combined with Vis/ NIR. Advanced Materials Research 320: 563-568.

Michael, D., Mingos, P. \& Baghurst, D.R. 1991. Application of microwave dielectric heating effects to synthetics problems in chemistry. Chemical Society Reviews 20: 1-47.

Microchip. 2015. 20-Pin Flash-Based, 8-Bit CMOS Microcontrollers. http://ww1.microchip.com/downloads/ en/DeviceDoc/40001262F.pdf.

Mini Circuits. 1999. Directional Couplers. https://www. minicircuits.com/app/COUP7-2.pdf.

Nagarajan, R., Singh, P. \& Mehrotra, R. 2006. Direct determination of moisture in powder milk using near infrared spectroscopy. Journal of Automated Methods and Management in Chemistry 2006: Article ID. 51342. 
Nelson, S.O. 2003. Frequency- and temperature-dependent permittivities of fresh fruits and vegetables from 0.01 to 1.8 GHz. Transactions of the ASAE 46: 567-574.

Nielsen, S.S. 2010. Food Analysis. 4th edition. USA: Springer.

Onu, L.I. \& Okafor, G.I. 2003. Effect of physical and chemical factor variations on the efficiency of mechanical slicing of Nigerian ginger (Zingiber officinale Rose). Journal of Food Engineering 56: 43-47.

Ragni, L., Gradari, P., Berardinelli, A., Giunchi, A. \& Guarnieri, A. 2006. Predicting quality parameters of shell eggs using a simple technique based on the dielectric properties. Biosystems Engineering 94: 255-262.

Rao, M.A., Datta, A.K. \& Rizvi, S.S. 2005. Engineering Properties of Food. Florida: Taylor \& Francis.

Ruan, R.R. \& Chen, P.L. 1998. Water in Foods and Biological Materials: A Nuclear Magnetic Resonance Approach. USA: Technomic Publishing Company.

Ryynnanen, S. 1995. The electromagnetic properties of food materials: A review of the basic principles. Journal of Food Engineering 27: 409-429.

SAS Institute. 1989. SAS/STAT User's Guide. Cary: SAS Institute.

Shukla, T.P. \& Anantheswaran, R.C. 2001 . Ingredient interactions and product development. In Handbook of Microwave Technology for Food Applications, edited by Datta, A.K. \& Anantheswaran, R.C. New York: Marcel Dekker. pp. 355-395.

Sigma Aldrich. 2003. HYDRANAL ${ }^{\circledR}$ - Manual http://www. sigmaaldrich.com .

Sreekumar, M.M., Sankarikutty, B., Menon, A.N., Padmakumari, K.P., Sumathikutti, M.A. \& Arumughan, C. 2002. Fresh flavoured spice oil and oleoresin. Spice India (English) 15: 15-19.

Thumm, M., Wiesbeck, W., Note, A., Huisman, J.A., Thakur, O.P., Singh, A.K. \& Authority, S. 2012. The relationship between loss, conductivity, and dielectric constant. Advanced Studies in Theoretical Physics 46: 1-12.

USAID. 2004. Ginger, post-harvest care and market preparation. Accessed from http://pdf.usaid.gov/pdf docs/PNACY839. pdf.

Venkatesh, M. \& Raghavan, G. 2004. An overview of microwave processing and dielectric properties of agri-food materials. Biosystems Engineering 88: 1-18.

Yahaya, N.Z., Abbas, Z., Ibrahim, N.M., Hafizi, M.H.M. \& Yahaya, M.Z. 2014. Permittivity models for determination of moisture content in Hevea Rubber Latex. International Journal of Agricultural and Biological Engineering 7: 48-54.
Yeh, R.S., Anantheswaran, R.C., Shenk, J. \& Puri, V.M. 1994. Determination of moisture profile in foods during microwave heating using VIS-NIR spectroscopy. Food Science and Technology 27: 358-362.

Nur Biha Mohamed Nafis, Zulkifly Abbas*, Jumiah Hassan \& Noradira Suhaime

Department of Physics, Faculty of Science

Universiti Putra Malaysia

43400 UPM Serdang, Selangor Darul Ehsan

Malaysia

Lee Kim Yee

Department of Electrical and Electronic Engineering

Faculty of Engineering and Science

Universiti Tunku Abdul Rahman

53300 Setapak, Kuala Lumpur, Federal Territory

Malaysia

You Kok Yeow

Department of Radio Communication Engineering (RaCED)

Faculty of Electrical Engineering

Universiti Teknologi Malaysia

81310 Skudai, Johor Darul Takzim

Malaysia

Zaulia Othman

Bank Gene and Seed Center

Malaysian Agricultural Research and Development Institute (MARDI)

MARDI Headquarters

Persiaran MARDI-UPM

43400 Serdang, Selangor Darul Ehsan

Malaysia

*Corresponding author; email: za@upm.edu.my

Received: 15 April 2018

Accepted: 27 July 2018 